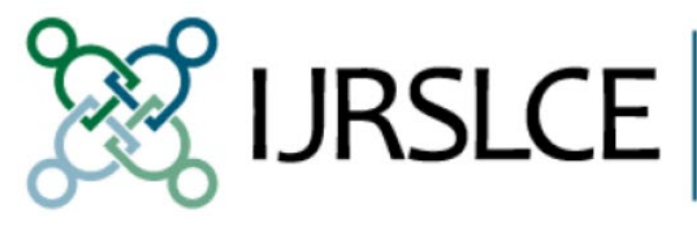

International Journal

for Research on

Service-Learning \&

Community Engagement

Volume 4 | Issue 1

Article 26

2016

\title{
Highlights from IARSLCE's Annual and Regional Conferences
}

\author{
Andrew Furco \\ Kateryna Kent
}

This article was originally published at:

https://journals.sfu.ca/iarslce/index.php/journal/article/view/250/177

Recommended Citation

Furco, A., \& Kent, K. (2016). Highlights from IARSLCE's annual and regional conferences.

International Journal of Research on Service-Learning and Community Engagement, 4(1), Article 26. 


\title{
Highlights from IARSLCE's Annual and Regional Conferences
}

\author{
Andrew Furco \\ Co-Editor \\ Kateryna Kent \\ Assistant Editor
}

As an international association, IARSLCE continues to find ways to broaden and deepen its membership and networks across the globe. Last year, in collaboration with other international groups, IARSLCE launched a set of regional conferences to convene researchers and practitioners from different parts of the world to further their service-learning and community engagement research agendas.

In this section of the journal, we highlight four papers presented at two regional conferences, one in South America and one in Europe. For the South American conference, IARSLCE collaborated with the Centro Latinoamericano de Aprendizaje y Servicio Solidario (CLAYSS; translated, Center for Latin American Service-Learning and Solidarity) - an international network that seeks to further servicelearning across Latin America and the Iberian Peninsula - to host a one-day research conference in Buenos Aires, Argentina, on August 26, 2015. At this Spanish-language conference, more than 100 individuals from over a dozen countries presented, discussed, and explored the latest research on servicelearning. In this issue of the journal, we present a translation of one of the peer-reviewed papers presented at this event. IARSLCE's European conference involved a partnership with two continental networksthe International Horizons network of the Siena Italian Studies and the Europe Engage Network-for a one-day, multinational, English-language research gathering in Bologna, Italy, on June 10, 2016. This event included more than 100 scholars from 16 countries. In this issue, we spotlight three of the peerreviewed papers that were presented at this conference.

Together, these four conference papers provide a glimpse into current international discussions on service-learning and community engagement research. They also offer information on the kinds of research studies that are needed to advance service-learning and community engagement in different community and cultural contexts. We extend our thanks to Maria Nieves Tapia, Maria Alejandra Herrero, Enrique Ochoa, Eliza Nash, Lavinia Bracci, Nevin Brown, Lorraine McIlrath, and Pilar Aramburuzabala for their leadership in hosting the conferences and facilitating the peer-review processes for the papers we present in this issue.

We are also very pleased to include in this volume Tania Mitchell's keynote panel presentation from IARSLCE's $15^{\text {th }}$ annual conference. Dr. Mitchell and several other panelists were asked to offer their perspectives on "seminal moments" and "under-examined areas" that are essential for the growth and vibrancy of the service-learning field. Dr. Mitchell identifies three seminal moments that have shaped her-and our-views of service-learning and community engagement, and describes how the emergence of a more critical discourse within the field influenced her decision to pursue a career as a servicelearning researcher and scholar. Her words highlight a rapidly evolving field in which our approaches to the study and practice of service-learning and community engagement are being transformed.

We hope you enjoy this new special section of the journal. 
